\title{
STATE AND USE OF LAKES FROM CENTRAL REGION OF THE REPUBLIC OF MOLDOVA
}

\author{
Bacal Petru' $^{1}$, Jeleapov Ana', Burduja Daniela ${ }^{1}$, Moroz Ivan ${ }^{1}$
}

Keywords: lakes, region, state, use, tourism, recreation.

\begin{abstract}
The article is dedicated to assessment of the state and use of lakes and reservoirs situated in the Central Region of the Republic of Moldova. The results showed that 1155 reservoirs and ponds with a total area of 11.4 ths. ha are situated in the limits of 14 districts. Over half of them are constructed on the streams. At the district level, the biggest number of lakes is located in Călărași (204), Orhei (139) and Ungheni (136), but the largest surface is attested in Ialoveni (1844 ha), Ungheni (1584 ha), Teleneşti (1358 ha). The reservoir basin status is satisfactory only in case of $1 / 3$ (381) of reservoirs, $40 \%$ being silted. Hydro-technical infrastructure is satisfactory at $\approx 2 / 3$ of reservoirs. The reservoirs are used for fishery (34\%), general use $(31 \%)$, irrigation $(13 \%)$, mixed use $(7 \%)$. Only 47 lakes or $12 \%$ are used mainly for recreational purposes.
\end{abstract}

\section{Introduction}

The lakes represent a substantial water resource, such that their role in water supply deserves a special attention. Interesting fact is that a total of $10800 \mathrm{~km}^{3}$ of water has been impounded on land to date, reducing the magnitude of global sea level rise by $-30.0 \mathrm{~mm}$, at an average rate of $-0.55 \mathrm{~mm} /$ year during the past half century (Chao et al, 2008). Thus, these water accumulations have a greater impact on local water cycle, and redistribution of water on continents. In Europe water used from lakes and, especially, reservoirs is $27.3 \mathrm{~km}^{3}$ (2015) [22] or $11.8 \%$ from the total.

In today's post-industrial society, requirements for water-much of which is derived from lakes, include its use for water supply of households, of industrial and agricultural companies, for power generation and cooling purposes, for dilution and removal of municipal and industrial wastes and for local recreation and aesthetic displays. Obviously, these requirements vary considerably among regions and

\footnotetext{
${ }^{1}$ Institute of Ecology and Geography, Chișinău, Republic of Moldova pbacal16@gmail.com, anajeleapov@gmail.com, dana.virlan@mail.ru,morozbye@yahoo.com,
} 
countries (Lane). The importance of reservoirs is expressed also by regulation of river flow, protection from floods, as well as tourism and recreation facility. Many lakes shores are arranged for this type of activity, as an example can serve reservoirs from Romania (Giurma et al, 2010: Romanescu et al, 2011), Poland, Hungary, Finland (Duda-Gromada et al, 2010; David et al, 2012), Canada (McNoughton, 1994).

The present research is dedicated to evaluate the state of lakes and reservoirs from the central part of the Republic of Moldova focusing also on estimation of their use, especially for tourism and recreation. It should be mentioned that in the present study, the terms of lakes and reservoirs was not used only for large accumulations of water (the themselves lakes and reservoirs), but also for the smallest ones (ponds etc.) formed or built on a natural environment both on water courses and on the side.

In the Republic of Moldova there are over 4,400 lakes, from which only 57 are of natural origin. The total surface of the lakes is about 40 thousand ha (cazac et al, 2010). Most lakes are located in the Prut and Dniester Rivers Basins, especially in the lower course of these rivers floodplains, especially in the lower course of these rivers. Most of these reservoirs were built in the 1970-1980 years, with the main purpose of regulating river flow and floods control (Boboc et al, 2012). They have gradually begun to be used extensively for irrigation and fishery purposes, often with disregard for hydro technical and ecological requirements, which has significantly affected the floodplain ecosystems and surface water reserves (Bejan et al, 2017). In addition, the largest reservoirs were managed by large fish farms, which were subsequently self-managed or privatized, and the level of record and monitoring of these aquatic objects by the responsible public authorities declined considerably. With the exception of large farms, there is no evidence of the use of lake water, especially for fishery, and the official data does not sufficiently reflect the use of water from these sources and their contribution to the local and regional economy. In addition, many reservoirs are silted, covered with vegetation or even have dried.

\section{Methodology}

For achieving of this study were applied the following methods: mathematical and statistical methods, ecological, analytical, cartographic and comparative methods. The statistical and mathematical methods have been applied to the processing of data on the state and use of lakes, evaluation of existing capacities of tourism and leisure infrastructure, as well as of visitor flows to lakes from region of study.

Ecological methods have been used to evaluate the status of lakes and reservoirs from study area. On the data from the environmental authorities (ICPA, 
2019), have been delimitated and analysed four infrastructure components: a) dam; b) riparian buffer; c) hydro-technical infrastructure; d) sluice (bottom evacuator).

The analytical method was used for assessment of lakes, especially of the status of the lakes and their main usage categories, of the level of recreational and recreational valorisation of these aquatic objectives and for identifying the key problems of public management of these aquatic objectives from region of study. The analysis of lakes use has also focused on the methodology stipulated in the WATECO Guidance on the economic assessment of water use (Guidance, 2003). Also, in order to carried out of present research was elucidated the analytical studies regarding the status and use of surface water on the hydrographical basins, especially from Romania (Apele Române, 2017; Giurma et al, 2017; IPM, 2019), Republic of Moldova (Bacal, Burduja, 2017; Bacal, 2017), Ukraine and other European countries (Danube, 2019; EPIRB, 2019).

For the spatial representation of the hydrographical network and the main lakes from the study region, were applied the modern cartographic methods, based on GIS techniques. Spatial information was partly extracted from National Geodata Fund (Geoportal, 2019) and processed using QGIS (2019). The comparative method was applied for analysis of the different usage categories of lakes and for identification of spatial differences and typology, both in the administrativeterritorial and in the basin profiles.

\section{Results and discussions}

2.1Basic characteristics of the lakes from the Central Region. The Central Region (CR) of the Republic of Moldova (RM) includes 13 districts, which form the Central Development Region (CDR), as well as the Chisinau municipality (Statistica, 2019), which forms the homonym development region (Fig. 1). The total area of the Central Region is 11.2 thousand $\mathrm{km}^{2}$ or $33 \%$ of the total area of the Republic. The area of the Central Development Region is 10.6 thousand $\mathrm{km}^{2}$ (31\%), and of Chişinău municipality is $568 \mathrm{~km}^{2}(1.7 \%)$. The population of the Central Region is 1.9 million inhabitants or $1 / 2$ of the total population of the Republic (Bacal, Burduja, 2017). In the central districts there are 1.1 million people (26\%), and in Chisinau - 814 thousand inhabitants (20\%).

According to data from Inspectorate of Environmental Protection (IPM, 2019), in the Central Region are located 1155 reservoirs and ponds with a total area of 11.4 thousand ha (Tab. 1). 623 reservoirs are constructed on the streams, and 532 - along the river. In the urban space, 55 lakes $(53 \%)$ built on the rivers, and 48 lakes $(47 \%)$ - arranged along the watercourses. The maximum number of lakes is arranged on the Botna, Răut, Ciulucul Mic, Delia, Gârla Mare, Nârnova, Lăpuşna and Sarata rivers. 
At the district level, most reservoirs are located in Călărași (no. 204), Orhei (no. 139) and Ungheni (no. 136), (Tab. 1). The maximum number of reservoirs in the Călăraşi district is due not only to more favorable natural conditions (bigger amount and uniform precipitation, more fragmented relief and dense of hydrographic network), but also to the higher level of record of these reservoirs realized by cadastral authorities (IPM, 2019). The total surface of lakes from Central DR is 10.4 thousand ha, and of Chișinău municipality is 1031 ha, including 742 ha occupied by the Ghidighici reservoir.

Reservoir surface is also conditioned by districts dimensions, degree of topography fragmentation and the density of the hydrographic network, the atmospheric precipitation and hydrological characteristics (Cazac et al, 2010; Bejan et al, 2017). Therefore, in the CDR the maximum lakes surface is attested in Ialoveni (1844 ha), Ungheni (1584 ha), Teleneşti (1358 ha) and Hincesti (1291 ha) districts, and the the smallest one - in the smallest districts, such as Dubasari (17 ha), Soldanesti (214 ha) and Rezina (283 ha).

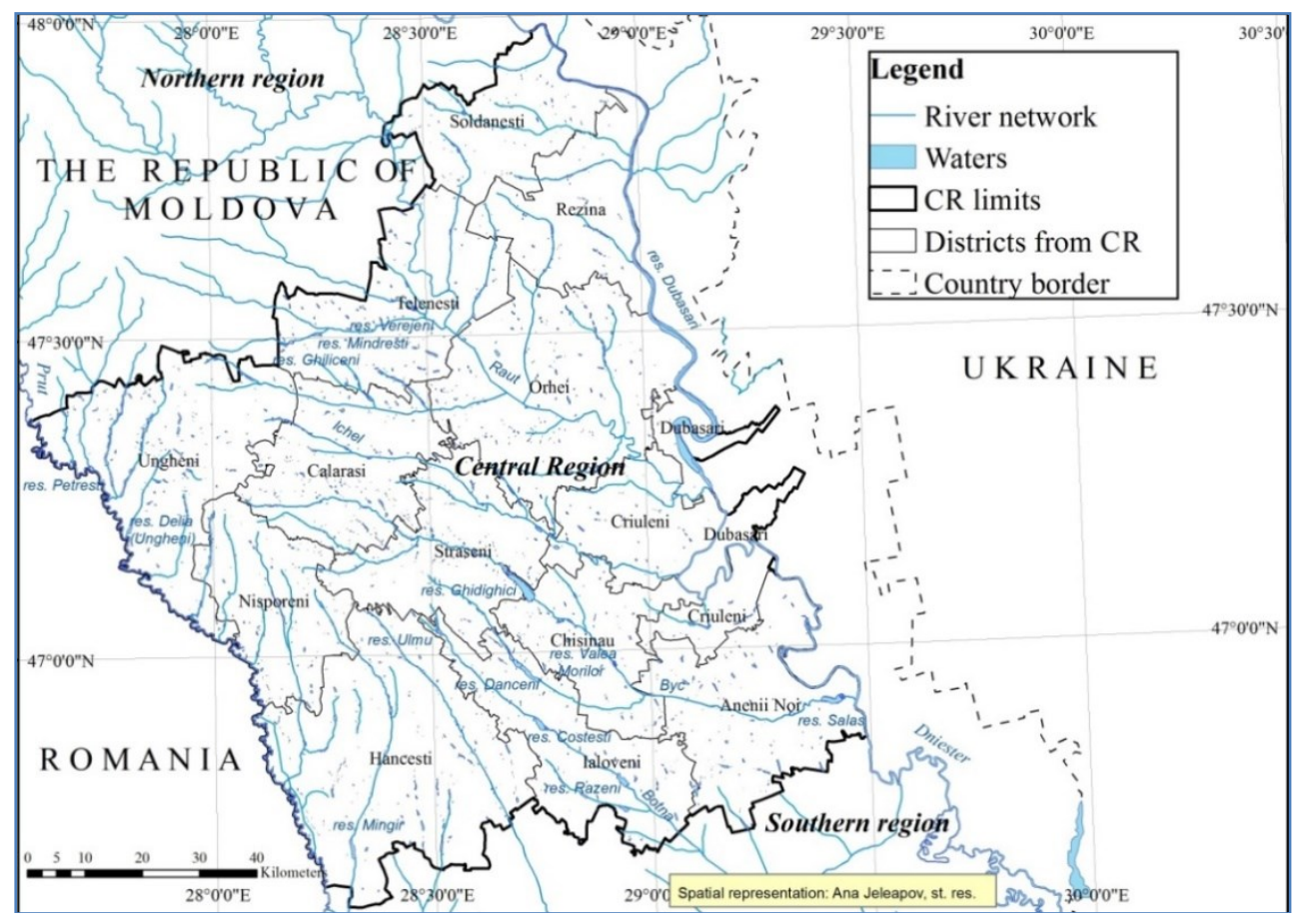

Fig. 1. The Central Development Region of Republic of Moldova (distrits, rivers and lakes). 
In the Ialoveni district are registered only 62 reservoirs, but their total surface exceeds by 3.2 times the reservoirs surface from Călărași district (Table 1). This is due, mainly, to the construction of a set of larger reservoirs in the 1970-1980 years in Dănceni (240 ha), Nimoreni (125 ha), Suruceni (111 ha), Sociteni (103 ha) localities, located along the Isnovăt river tributary of the Bâc river, and from Horăşti, Răzeni (102 ha) and Costeşti (231 ha) settlements, located along the Botna river (Fig. 1).

Table 1. Location and usage categories of lakes from the Central Region of RM

\begin{tabular}{|c|c|c|c|c|c|c|c|c|c|c|}
\hline \multirow{2}{*}{$\begin{array}{c}\text { Districts/ } \\
\text { municipality }\end{array}$} & \multirow{2}{*}{ No. } & \multirow{2}{*}{ Surface } & \multicolumn{2}{|c|}{ Location } & \multicolumn{6}{|c|}{ The main usage categories } \\
\hline & & & Lateral & On course & fishery & general & irrigation & recreation & mixed & others \\
\hline Şoldăneşti & 59 & 214 & 1 & 58 & 41 & 12 & 3 & & & 3 \\
\hline urban & 4 & 11 & & 4 & 1 & & 1 & 2 & & \\
\hline Rezina & 46 & 286 & 20 & 27 & 7 & & 4 & 2 & 11 & 22 \\
\hline Telenești & 99 & 1358 & 91 & 8 & 8 & 79 & 12 & & & \\
\hline urban & 7 & 61 & 7 & & & 7 & & & & \\
\hline Orhei & 139 & 953 & 20 & 119 & 40 & 45 & 22 & & 31 & 1 \\
\hline urban & 1 & 39 & & 1 & & 1 & & & & \\
\hline Criuleni & 64 & 349 & & 64 & 24 & & 14 & 19 & 7 & \\
\hline Anenii Noi & 45 & 889 & 2 & 43 & 18 & 18 & 9 & & & \\
\hline urban & 3 & 12 & & 3 & & 3 & & & & \\
\hline Ialoveni & 62 & 1844 & 38 & 24 & 16 & 11 & 3 & & 32 & \\
\hline Străşeni & 53 & 355 & 47 & 6 & 19 & 29 & 4 & & & 1 \\
\hline urban & 1 & 3 & & 1 & & 1 & & & & \\
\hline Călăraşi & 204 & 570 & 200 & 4 & 66 & & 27 & 111 & & \\
\hline urban & 19 & 46 & 19 & & 5 & & & 13 & & 1 \\
\hline Ungheni & 136 & 1584 & & 136 & 59 & 68 & 9 & & & \\
\hline urban & 3 & 125 & & 3 & 2 & 1 & & & & \\
\hline Nisporeni & 73 & 664 & 26 & 47 & 13 & 54 & 5 & & & 1 \\
\hline Hâncești & 111 & 1291 & 61 & 50 & 63 & 41 & 3 & & & 4 \\
\hline urban & 11 & 56 & 5 & 6 & 11 & & & & & \\
\hline Dubăsari & 10 & 17 & 10 & & 1 & 2 & & & & 7 \\
\hline Central DR & 1101 & 10374 & 516 & 586 & 375 & 359 & 115 & 132 & 81 & 39 \\
\hline mun. Chișinău & 54 & 1031 & 17 & 37 & 18 & 4 & 32 & & & \\
\hline Total & 1155 & 11404 & 533 & 622 & 393 & 363 & 147 & 132 & 81 & 39 \\
\hline Urban area & 103 & 1383 & 48 & 55 & 37 & 17 & 33 & 15 & & 1 \\
\hline
\end{tabular}

Data source: Inspectorate for Environmental Protection

Also, is remarkable the lake Sălaș, with 345 ha, located in Gura Bâcului village from Anenii Noi district. In Teleneşti district, 3 reservoirs with over 60 hectares were built in the Ciuluc river basin Verejeni (212 ha), Ghiliceni (97.3 ha) and Mândrești (63.6 ha), which are in private property and used for fishery. The 
largest reservoirs in the Ungheni district are located in Ungheni city (104 ha) and Agronomovca village (103 ha) on the Delia river; in Petreşti village, including 3 lakes (161 ha) on the Şoltoaia river and 1 lake (61 ha) - on the Gârla Mare river; in Zagarancea (63 ha) and Bumbăta (67 ha), both being constructed on the Vladnic river. In Hâncesti district can be mentioned the reservoirs from Mingir (322 ha) and Lăpuşna (78 ha), and in Orhei district - from Brăviceni (74 ha) and Ivancea (144 ha).

On the urban lands of the Central Region are located 103 lakes, including 49 in the districts of Central DR and 54 lakes - from Chișinău municipality. In Central DR, the maximum number of lakes is arranged on the lands of Călăraşi (19) and Hânceşti (11) cities. The area of urban lakes is 1.4 thousand ha, including 1031 ha in the municipality of Chisinau and 352 ha in the urban area. The maximum area occupied by lakes and reservoirs is specific for Ungheni (125 ha), Teleneşti (61 ha), Hânceşti (56 ha), Călăraşi (46 ha) and Orhei (39 ha).

2.2The lakes status. The agricultural and tourist use of reservoirs is conditioned not only by water quality, but also by their hydro-morphological status and the hydro technical facilities necessary for an efficient maintenance. According to the Inspectorate of Environmental Protection (IPM, 2019), the dam status at the absolute majority ( $88 \%)$ of the lakes from Central Region is satisfactory. The dam of 107 reservoirs $(9.3 \%)$ is damages. The biggest number of damaged dams is recorded in Orhei (17), Ialoveni (16) and Ungheni (14) districts. In addition, the dams are missing at 18 lakes in Călărași district and 8 lakes in Hâncesti district (Tab. 2). At the same time, in some districts this information is not updated and the real state of the dam is deplorable.

The reservoir basin status is satisfactory only in about of $1 / 3$ (381) of reservoir from the Central Region. The minimum share of lakes with satisfactory basins is attested in the Călărași (0\%), Dubăsari (10\%) and Anenii Noi (11\%) districts, and the maxim share - in the Straseni (96\%), Ungheni (71\%), Nisporeni (58\%) and Hâncești (51\%) districts, as well as in Chisinau (50\%). Over 40\% of the study region's lakes are silted, which significantly limits both agricultural, fishery or tourism usages, as well as the ecological and hydro-technical functions of the respective basins. The maximum share of silted basins is observed in Şoldănești (97\%), Anenii Noi (71\%), Rezina (70\%) and Călăraşi (61\%) districts and the minimum share - in Chisinau municipality and in Străşeni, Dubăsari, Ungheni and Teleneşti districts (IPA, 2019). About 15\% of the lakes basins from Central Region are massively covered with vegetation, and the maximum share of these basins are attested in Teleneşti (59\%) and Călăraşi districts (38\%). 10\% of the reservoirs basins from study region are dry and the maximum share of dry basins is attested in districts of Dubăsari (70\%), Rezina (30\%), Criuleni (22\%). 
Regarding to the riparian forest buffer, the situation is better, because it is present in about $3 / 4$ of the region's lakes. At the same time, in some districts a large number of lakes do not have such a buffer, including Străseni $(60 \%)$, Criuleni (58\%), Ialoveni (52\%) and Hâncesti (46\%). In Chişinău, riparian buffer exist at $\approx$ $90 \%$ of the lakes and $54 \%$ of them are forested because the lakes are located in or near parks.

The status of the hydro-technical infrastructure is satisfactory at $\approx 2 / 3$ of lakes from the Central Region, and the best situation is found in Străseni, Teleneşti, Ungheni, Criuleni, Hâncesti and Chișinău districts. At the same time, more than $30 \%$ of the lakes hydro - technical installations are absent, including in the districts of Dubăsari (90\%), Călărași (57\%), Anenii Noi (53\%), Nisporeni (48\%) and Orhei (42\%).

Table 2. The status of lakes and reservoirs in the Central Region

\begin{tabular}{|c|c|c|c|c|c|c|c|c|c|c|c|c|c|c|c|c|c|}
\hline \multirow{2}{*}{ 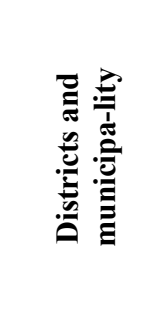 } & \multirow[b]{2}{*}{ Nr. } & \multicolumn{3}{|c|}{ Dam status } & \multicolumn{4}{|c|}{ The basin status } & \multicolumn{3}{|c|}{$\begin{array}{c}\text { Status of } \\
\text { riparian } \\
\text { buffer }\end{array}$} & \multicolumn{3}{|c|}{$\begin{array}{c}\text { Status of } \\
\text { hydro- } \\
\text { technical } \\
\text { structures }\end{array}$} & \multicolumn{3}{|c|}{$\begin{array}{l}\text { Status of the } \\
\text { slice }\end{array}$} \\
\hline & & 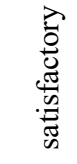 & 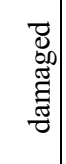 & $\stackrel{-4}{ٍ}$ & 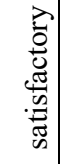 & $\stackrel{\vec{D}}{\overparen{E}}$ & 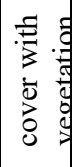 & $\vec{\theta}$ & $\cdot \overrightarrow{\vec{n}}$ & $\stackrel{\breve{O}}{\Xi}$ & $\begin{array}{l}\vec{d} \\
\mathbb{0} \\
\stackrel{0}{0} \\
0\end{array}$ & 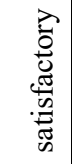 & 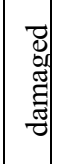 & $\stackrel{\breve{C}}{\Xi}$ & 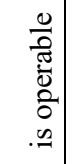 & 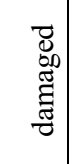 & $\stackrel{\frac{y}{ٍ}}{\Xi}$ \\
\hline Șoldănești & 59 & 58 & 1 & & & 57 & & 2 & 57 & 5 & & & & 59 & 59 & & \\
\hline Rezina & 46 & 32 & 14 & & & 32 & & 14 & 35 & 11 & & 24 & 19 & 3 & 21 & 25 & \\
\hline Telenești & 99 & 90 & 9 & & & 26 & 58 & 15 & 93 & 6 & & 88 & 8 & 3 & 84 & 13 & 2 \\
\hline Orhei & 139 & 122 & 17 & & 29 & 67 & 18 & 25 & 105 & 32 & 2 & 75 & 6 & 58 & 66 & 6 & 67 \\
\hline Criuleni & 64 & 59 & 5 & & 21 & 29 & & 14 & 27 & 20 & 17 & 55 & 1 & 8 & 50 & 3 & 11 \\
\hline Anenii Noi & 45 & 39 & 6 & & 5 & 32 & 1 & 7 & 30 & 10 & 5 & 16 & 5 & 24 & 13 & 6 & 26 \\
\hline Ialoveni & 62 & 46 & 16 & & 28 & 17 & 12 & 5 & 30 & & 12 & 43 & 2 & 17 & 46 & 16 & \\
\hline Străşeni & 53 & 53 & & & 51 & & & 2 & 21 & 1 & 31 & 53 & & & 52 & & 1 \\
\hline Călărași & 204 & 186 & & 18 & & 125 & 77 & 2 & 193 & & 11 & 88 & & 116 & 72 & & 116 \\
\hline Ungheni & 136 & 122 & 14 & & 97 & 35 & & 4 & 79 & 57 & & 121 & 5 & 10 & 71 & 65 & \\
\hline Nisporeni & 73 & 68 & 5 & & 42 & 28 & 2 & 1 & 67 & 6 & & 36 & 2 & 35 & 45 & & 28 \\
\hline Hâncești & 111 & 96 & 7 & 8 & 57 & 38 & & 16 & 60 & 51 & & 98 & 3 & 10 & 92 & 1 & 8 \\
\hline Dubăsari & 10 & 2 & 8 & & 1 & 2 & & 7 & 10 & & & 1 & & 9 & 1 & 9 & \\
\hline Chișinău & 54 & 49 & 5 & & 50 & 4 & & & 48 & 6 & 29 & 47 & 2 & 5 & 12 & & 42 \\
\hline Total & 1155 & 1022 & 107 & 26 & 381 & 492 & 168 & 114 & 855 & 205 & 107 & 745 & 53 & 357 & 684 & 144 & 301 \\
\hline
\end{tabular}

Data sources: Inspectorate for Environmental Protection

An important role in the realization of the ecological and hydrological functions is played by the sluice, which is present for $\approx 60 \%$ of the reservoirs from 
the study region, including in Şoldăneşti (100\%), Străşeni (98\%), Teleneşti (85\%), Hânceşti (83\%), Criuleni (78\%) and Ialoveni (74\%) districts. At the same time, operable bottom evacuators are missing at about $1 / 3$ of the lakes, including reservoirs from Chisinau (78\%), and from Anenii Noi (58\%), Călărași (57\%) and Orhei $(48 \%)$ districts.

2.3 The general aspects of lakes use in the Central Region. Over 1/3 (34\%) of the total number of registered lakes in the Central Region are attributed to fishing purposes (Tab.1), including industrial, amateur and sport fishing. The maximum number of reservoirs designated as priority for fish farming is attested in the districts of Călărași (66), Hâncești (63) and Ungheni (59). Most of the urban lakes used for fish farming are in Chișinău (18) and, also, in the towns of Hâncești (11) and Călărași (5), being used massively not only for industrial fishing, but also for sport and amateur fishing and other associative recreation activities.

Over 360 reservoirs (31\%) are attributed to general use, including 17 lakes on the urban lands (David et al, 2012). Most of these reservoirs are located in Teleneşti (79), Ungheni (68), Nisporeni (54) and Orhei (45) districts. Also, the maximum number of lakes in urban areas assigned for general use is recorded in Teleneşti (7) and Chisinau (4), but the maximum area - in Ungheni (104 ha) and Teleneşti (61 ha) towns. The majority of reservoirs for general use are managed by the town halls and are frequently used for recreation of the local population and visitors. Most owned or leased reservoirs are used for fishing, irrigation and commercial recreation purposes.

For irrigation purposes are assigned 147 lakes or 13\% of the total number of lakes registered in the Central Region (Table 1). The vast majority of irrigation lakes are located in the Dniester river basin, which has much larger water reserves compared to the Prut and Cogâlnic rivers basins (Cazac et al, 2010). The maximum number of lakes attributed to irrigation is attested in the settlements of Chisinau municipality (32) and is due to the more intensive nature of suburban agriculture, as well as in the districts of Călărași (27), Orhei (22) and Anenii Noi (20). In addition, for irrigation purposes are also used a big number of the reservoirs assigned to general and mixed use.

For mixed use, including for irrigation, fishery and agreement, are assigned 81 lakes (7\%), located in the districts of Ialoveni (32), Orhei (31) and Rezina (11). In addition, in the Codri scientific reserve near Lozova village from Strășeni district, there is an private reservoir with an area of 1.1 ha and designated for scientific research.

2.4 Tourist and recreational use of the lakes from the region of study. For priority recreational purposes, are assigned 47 lakes or $12 \%$ of the total number of 
lakes from Central Region. At the same time, more than $3 / 4$ of the total lakes attributed to these purposes are located in the Călărași district, including 13 lakes in Călărași town, out of which 11 small lakes $(\leq 1 \mathrm{ha})$. Also, in the Criuleni district are located 19 recreational reservoirs. The largest urban used for leisure are located in Ungheni (104 ha) and Anenii Noi (12 ha) towns. The other lakes are smaller (IPM, 2019).

For recreational purposes, usually unorganized, are used the most municipalities' reservoirs assigned to general use, especially from the urban settlements or nearby areas, and the access of local populations and visitors is much easier compared to those leased and used for fisheries ponds (Bacal, Burduja, 2017). In addition, recreation functions also provide 63 lakes with mixed use, as well as a large part of the with fishery destination.

In the proximity of the reservoirs from the Central Region there are only 2 spa resorts (Tab. 3): 1) "Struguraş" on the left bank of the Dubasari reservoir, built on the Dniester river; 2) "Codru" - near the Hârjauca village from Călărași district.

Table 3. The balneo-climatic resorts near the lakes from Central Region

\begin{tabular}{|l|l|c|c|c|c|c|c|c|}
\hline \multirow{2}{*}{$\begin{array}{c}\text { The name } \\
\text { of resort }\end{array}$} & \multirow{2}{*}{ Location } & \multicolumn{1}{|c|}{$\begin{array}{c}\text { Accommodation } \\
\text { capacity }\end{array}$} & \multicolumn{5}{|c|}{ Number of clients } \\
\cline { 3 - 9 } & & seats & $\mathbf{0 0 m s}$ & $\mathbf{2 0 1 4}$ & $\mathbf{2 0 1 5}$ & $\mathbf{2 0 1 6}$ & $\mathbf{2 0 1 7}$ & $\mathbf{2 0 1 8}$ \\
\hline Codru & Hârjauca, Călăraşi d. & 464 & 257 & 10325 & 10623 & 10743 & 9965 & 10500 \\
\hline Strugruraș & Cocieri, Dubăsari d. & 300 & 158 & 4735 & 4763 & 4872 & 3435 & 2423 \\
\hline Total & & $\mathbf{7 6 4}$ & $\mathbf{4 1 5}$ & $\mathbf{1 5 0 6 0}$ & $\mathbf{1 5 3 8 6}$ & $\mathbf{1 5 6 1 5}$ & $\mathbf{1 3 4 0 0}$ & $\mathbf{1 2 9 2 3}$ \\
\hline
\end{tabular}

Data source: resorts administration (www.otdyh.md)

The "Codru" balneo-climatic resort is the first settlement (1959) of this type in the Republic of Moldova. It is located in the central part of Codrii Plateau, on the territory of the Hârjauca village from Călăraşi district. Also called "The Codri's Pearl" is the most popular balneo-climatic resort in the Republic of Moldova for treatment of gastrointestinal and renal diseases, central and peripheral nervous system, respiratory tract, locomotion system traumas, gynaecological diseases and chronic prostatitis [9]. For treatment are used local mineral waters with sodium hydrocarbon sulphate, therapeutic mud, medicinal plants and apiculture products from this zone. In addition, the very comfortable microclimate and high air quality in the area generate special therapeutic effects and a high and permanent demand for the resort (Bacal et al, 2012).

"Codru" resort has 464 beds or over $30 \%$ of the total accommodation capacity of the spa resorts in the Republic, including 35 single rooms, 200 double rooms and 16 suites. The price of a 10 day resting ticket, including accommodation, 5 meals 
per day, and basic treatment starts from 4300 MDL per person. The occupancy rate of resort exceeds $80 \%$ per year, and in the summer months and around the traditional winter holidays it is full. In the rest of the year is occupied over $2 / 3$ of the accommodation capacity. The number of visitors per year is about 10 thousand persons (Table 3 ) or $1 / 3$ of the total number of spa resorts in the Republic of Moldova. The resort is in an active process of modernization, and accommodation, treatment and leisure services have an integrated character throughout the year (David et al, 2012).

Just a few hundred meters from the resort there is a 23 -acre reservoir arranged for sport fishery and for other recreation activities. The lake was recently rebuilt and has a organized beach, boats station for fishery and boating, camping and leisure facilities. Near the resort there are 4 of the most visited monasteries from the country: Răciula, Frumoasa, Hârbovăţ and Hârjauca, and in the Mândra village, inhabited by lipovans, can be found an old wooden church (18th century).

In Palanca village is a recently restored old wooden church (XV century), as well as the "Casa Țăranească"/"Traditional House", and in Răciula village - the monastery of nuns, the museum of Stalinist deportations and the Honey House "Casa Mierii". The listed objectives offer a varied and very interesting program of stay for the clients, and generate a higher attraction of this spa resort (Bacal, Cocos, 2012).

The spa resort "Strugurass" is located in a wonderful park on the left bank of the Dubăsari reservoir at a distance of $10 \mathrm{~km}$ from Dubăsari towns and at $50 \mathrm{~km}$ from Chișinău city. The accommodation capacity is of 300 seats in 158 rooms. The accommodation building also has 1 restaurant, which is linked to the therapeutic block through a gallery. Sanatorium "Struguraş" is recommended for treating diseases of the locomotion system, peripheral nervous system, gastrointestinal diseases, liver and gallbladder, respiratory organs, gynaecological and urological diseases (www.struguras.md, 2019). The minimum price for a stay per person is $5150 \mathrm{MDL}$ and includes 12 accommodation days, 3 meals/day and 3 procedures/day. The riparian area of the Dubasari reservoir is well equipped with leisure facilities highly appreciated both by the clients of the spa resort "Struguraş" as well as of various categories of visitors to the spa resort, especially by people who are invited to traditional festivities (weddings, baptisms, birthdays, corporate parties, etc.) that occur frequently in this place. In addition, from the deck in front of the resort can be organized the excursions on the Dniester river.

At the same time, most of the existing facilities, especially from the riparian recreation area, were built during in the Soviet period, and some of them were partially damaged and urgently needed to be renovated. The tourist and spa attraction of the area was significantly affected by the armed conflict on the Dniester, which was triggered, in 1991-1992 years, with great intensity in this zone 
(Bacal, Cocoș, 2012). In the proximity of the resort, in the Cocieri village and in other neighbouring villages (Coșnița) have taken place some of the longest and bloody battles with Transnistrian paramilitary structures, massively assisted by the 14th Army of the Russian Federation. Currently, the passage to the resort and to other neighbouring localities is allowed only after rigorous control by the special structures of the separatist authorities. As a result, the visitor flows to the resort and to this tourist zone are much lower compared to the Soviet period.

For the Chisinau city, a major recreational importance holds the Ghidighici reservoir, which covers an area of 742 ha along the road route between Vatra and Strășeni towns. Due to the unsatisfactory sanitary-hygienic status, the increased security requirements and the massive lack of leisure infrastructure, visitor access is significantly limited, and tourist flows are insignificant. In winter, the lake is most frequently visited by amateur and professional fishermen, and in summer by the clients of corporate recreation camps with limited access, as well as by visitors from neighbouring villages, who practice an unorganized recreation, especially on the left bank of the lake, which is not arranged. On the banks and near of reservoirs from the study region there are numerous rest camps, especially for the summer rest of the children, which were built during the Soviet period, especially in the districts of Orhei and Călărași, ămunicipality (Bacal, Cocoș, 2012). In addition, recently there were built the modern recreation complexes, such as the tourist and fishing complexes in Dănceni, Costești and Horăști villages from Ialoveni district, Braviceni and Ivancea from Orhei district, as well as in the districts of Straseni, Călărași and Telenești (fishhuntplaces.com).

Most of the lakes where are provided the sport fishing services are located near of Chisinau, including in the districts of Ialoveni (9), Strășeni (3), Anenii Noi and Orhei (2 each), Criuleni as well as in the localities from Chișinău municipality. The price for non-industrial fishing on the lakes in the Central Region is, on average, $130 \mathrm{MDL} /$ day, and varies from $50 \mathrm{MDL} /$ day up to $350 \mathrm{MDL} / \mathrm{day}$, depending on the species of fish allowed for fishing, by the comfort level and the degree of endowment with leisure facilities and fisheries of the location, and by other provided auxiliary services $[25,26]$. Most frequently caught fish species are carp, caras, sparrow, flax, plaice, mackerel, shawl, and rarely - mackerel, clean, sea bass, hickory, slumber and blood.

Most of the accommodation structures located near the reservoirs were built after 2000 and are private. The "Sadova" rest base near the homonymous village of Călărași district was built in 1993 and has the largest accommodation capacity, which includes 63 rooms, with 270 beds, (Tab. 4) intended, especially for the recreation of fishermen associations, sports and tourist clubs, private companies etc. 
The "Costești" tourist complex covers an area of 6 ha and is located in the Ialoveni district, only about $20 \mathrm{~km}$ away from the capital center and from Chisinau airport. It is located along the river Botna in a green area in the Costești village from the Ialoveni district. The complex was founded in 2001, and at present has 2 hotels, with an accommodation capacity of over 80 places, 2 banquet rooms, with a capacity of up to 250 persons, terraces, football, volleyball and football fields, tennis court, swimming pool, leisure facilities. The villa of the complex is equipped with fireplace, sauna, kitchen, conference room and 8 accommodation rooms. The sidewalks have 15 terraces, with a capacity from 20 to 100 persons, equipped with barbecue, aqueduct, electricity and refrigerator. The piscine is a separate leisure area, which includes 2 pools (large and small), sun loungers and terraces, bar, fastfood kitchen.

Table 4. The main accommodation structures at the lakes from the Central Region

\begin{tabular}{|c|c|c|c|c|c|}
\hline $\begin{array}{c}\text { The name of } \\
\text { resort }\end{array}$ & $\begin{array}{c}\text { Found in } \\
\text { year }\end{array}$ & $\begin{array}{c}\text { Comfort } \\
\text { categories }\end{array}$ & $\begin{array}{c}\text { Number of } \\
\text { rooms }\end{array}$ & $\begin{array}{c}\text { Number } \\
\text { of beds }\end{array}$ & Leisure facilities \\
\hline $\begin{array}{c}\text { The “Costești" } \\
\text { tourist complex }\end{array}$ & 2001 & 3 & 37 & 80 & $\begin{array}{c}\text { pool, soccer, basketball an } \\
\text { tennis courts, sidewalks. }\end{array}$ \\
\hline The pension „Fenix" & 2008 & 4 & 9 căsuțe & 52 & Sauna, sidewalks. \\
\hline $\begin{array}{c}\text { The tourist complex } \\
\text { „Festival” }\end{array}$ & 2014 & 3 & 20 & 60 & $\begin{array}{c}\text { Swimming pool, sports } \\
\text { ground }\end{array}$ \\
\hline $\begin{array}{c}\text { The rest base } \\
\text { "Sadova" }\end{array}$ & 1993 & 2 & 63 & 270 & $\begin{array}{c}\text { Swimming pool, sports } \\
\text { ground }\end{array}$ \\
\hline
\end{tabular}

Data sources: [23, 25]

The "Festival" tourist complex was founded in 2014 and is located within a rustic and wonderful landscape in the Palanca village from the Călărași district. The complex is intended for cultural festivals, especially popular music and instrumental music. For the rest of the visitors there are offered 20 rooms, with 60 places of accommodation, the Museum "Casa Părintească", the old wooden church (15th century), exhibition spaces for sale of traditional wooden works, embroidery and traditional manufacturing. The tourist pension "Fenix" is located on the right bank of Ghidighici reservoir and has 9 small houses, with 52 accommodation places, swimming pool, soccer and basketball fields, tennis court, sidewalks, sauna, etc.

The intensity of the tourist flows is also conditioned by the presence and level of comfort of the food and leisure structures. The food and recreation structures attract the majority of visitors to the tourist stops arranged at the reservoirs located near the main road routes and in the proximity of the capital. In addition, some of them not only offer traditional visitor feeding services, but also organizes various 
traditional and corporate banquets, which enjoy great popularity. Among the analysed food structures, the biggest reception capacity have the restaurant "Grand Radog", with 4 rooms and 560 seats, the tourist complexes "Costești" and "Festival" described above (Tab. 5).

Table 5. Tourist supply structures near the lakes from the Central Region

\begin{tabular}{|c|c|c|c|c|}
\hline The name of resort & $\begin{array}{c}\text { Foundatio } \\
\text { n year }\end{array}$ & $\begin{array}{c}\text { Number } \\
\text { of rooms }\end{array}$ & $\begin{array}{c}\text { The room } \\
\text { capacity, seats }\end{array}$ & Location \\
\hline Restaurant "Grand Radog" & 2013 & 4 & $\begin{array}{c}1-40 ; 2-60 \\
3-180 ; 4-280\end{array}$ & $\begin{array}{c}\text { Route Chișinău-Hâncești, on } \\
\text { the left bank of Dănceni lake }\end{array}$ \\
\hline Restaurant "Forestclub" & 2009 & 1 & 100 & Cărbuna village, Ialoveni d. \\
\hline Restaurant "Lacul Verde" & 2005 & 1 & 45 & Strășeni town \\
\hline Rest House „Casa Mierii"” & 2002 & 1 & 50 & Răciula village, Călărași d. \\
\hline Rest base "Sadovo" & 1993 & 1 & 270 & Sadova village, Călărași d. \\
\hline Tourist complex "Festival” & 2014 & 2 & $1-80 ; 2-115$ & Palanca village, Călărași d. \\
\hline Tourist complex "Costești" & 2001 & 2 & $1-200 ; 2-250$ & Costești village, Ialoveni d. \\
\hline
\end{tabular}

Data sources: www.complexturisticcostesti.md, www.otdyh.md

In the central part of the Orhei city there is the homonymous lake, with an area of 38 ha. On the bank of the lake was built the "Orheiland" Amusement Park the most attractive place for children and youth in the Republic of Moldova (www.otdyh.md, 2019). In order to ensure the high quality requirements for bathing water, the lake water is treated with the most modern facilities, which is a unique case for the Republic of Moldova. The "Orheiland" amusement park has an area of 20 thousand $\mathrm{m}^{2}$ and a capacity of over 50 thousand people/day, and is free for all visitors. The park was launched on June 1, 2018 and attracted over 500 thousand visitors only in the summer season. It is equipped with dozens of inflatable slides, trampolines and playgrounds for children, rails and suspended bridges, as well as a play area specially designed for children with disabilities. In the center of the green area is built a musical colour fountain. The basic attraction of the park is the American roller coaster, with a length of 350 meters.

\section{Conclusions}

The maximum number and of lakes and reservoirs are located in the districts of Călărași, Orhei and Ungheni, which are characterised both by maximal relief fragmentation and rainfalls, higher density of the hydrographical network, and by more complete evidence of these aquatic objectives. Also, the biggest lakes are located in the wider river valleys with a lower degree of fragmentation of the relief, 
including on the courses of the Botna, Răut, Bâc, Delia, Nârnova, Lăpuşna and Sarata rivers.

Overall, the status of the reservoirs in the Central Region of Republic of Moldova is satisfactory. A better situation is found in the status of riparian buffers, dams and of hydro-technical infrastructure. However, the unsatisfactory status of water basins is registered at over $2 / 3$ of lakes from study area, and $42 \%$ of reservoirs are silted, which significantly limits both agricultural, fishery or tourism usages, as well as the ecological and hydro-technical functions of the respective aquatic objectives. Most of these reservoirs were built in the 1970-1980 years, with the main purpose of regulating river flow and floods control. Subsequently, the majority of reservoirs were used extensively for irrigation and fishery purposes, often with disregard for hydro technical and ecological requirements, which has significantly affected the floodplain ecosystems and surface water reserves.

At the present, about $1 / 3$ of the lakes from the Central Region are allocated for fishing purposes and for general use, 13\% for irrigation purposes and $7 \%$ for mixed use. For priority touristic and recreational purposes, are assigned $12 \%$ of the total number of lakes in region of study. Also, for these purposes are used most of the municipalities' lakes for general and mixed use, and a large part of fishing lakes, were arranged the majority of recreational facilities.

Despite the presence of numerous reservoirs and the proximity of Chisinau, the tourism and recreational potential of these objectives is insufficiently exploited. The main causes are: 1) the unsatisfactory status of many aquatic objectives and their protection areas; 2) the massive depopulation of the rural area and the shortage of skilled labour force at the destination; 3) the acute insufficiency of the accommodation and infrastructure; 4) the poor condition of the access roads; 5) superficial record of visitors flows and of the revenues from the provision of these services.

\section{References:}

1. Bacal P., Burduja D. (2017). The regional pecularities of water use in the Republic of Moldova În: .Lucr. Seminar. Geogr. „D. Cantemir”, Vol. 46, Nr. 2. Iași, p. 19-37.

2. Bejan, I. et al (2017), Planul de gestionare a districtului bazinului hidrografic DunăreaPrut și Marea Neagră, Chisinau, $150 \mathrm{p}$.

3. Boboc N., Bejan I., Jeleapov, A. (2012), Inundațiile în natură și în viața omului, Mediul Ambiant., Nr. 2 62), Chișinău, p. 10-12, https://ibn.idsi.md/ro/

4. Cazac, V., Mihăilescu, C., Bejenaru, Gh. (2010), Resursele acvatice ale Republicii Moldova. Apele de Suprafață, Chișinău, Ed. Știința, 248 p.

5. Chao B.F., Wu Y.H., Li Y.S. (2008), Impact of Artificial Reservoir Water Impoundment on Global Sea Level, Science 2008, Apr. 11, 320 (5873):212-4.

DOI: $10.1126 /$ science. 1154580 
6. David L., Baros Z., Patkos C., Tuohino A. (2012), Lake Tourism and Global Climate Change:an integrative approach based on Finnish and Hungarian case-studies, Carpathian Journalof Earth and Environmental Sciences, 1, 2012, 121-136.

7. David S., Melnic N., Popa T. (2009), Stațiunea balneoclimaterică „,Codru" la 50 de ani, Chișinău, 96 p.

8. Duda-Gromada K., Bujdoso Z., David L. (2010), Lakes, reservoirs and regional development through some examples in Poland and Hungary, GeoJournal of Tourism and Geosites, 1 (5).

9. Giurma, I., Giurma-Handley, C.R., Crăciun, I. (2010), Impactul lacurilor de acumulare asupra mediului, Ed. Performantica, Iași.

10. Minea, I. (2013), Bazinul hidrografic Bahlui. Studiu hidrologic. Edit. UAIC. Iași, 334p.

11. McNaughton R.B. (1994), Economic benefits of recreation sites on irrigation reservoirs in southern Alberta, Canadian Water Resources Journal, 19:1, 3-16.

12. Romanescu G., Stoleriu C., Romanescu A.M. (2011), Water reservoirs and the risk of accidental flood occurrence. Case study: Stanca - Costesti reservoir and the historical floods of the Prut river in the period July-August 2008, Hydrological Processes, 25 (13):2056-2070. https://doi.org/10.1002/hyp.7957

13.***(2003), Guidance document nol. Economics and the Environment. The Implementation Challenge of the Water Framework Directive. Luxembourg:

14.***(2019), Inspectoratul pentru Protecția Mediului, Anuarele privind calitatea factorilor de mediu şi activitatea Inspecţiilor Ecologice din RD Centru și Agenţiei Ecologice Chișinău (2018).

https://www.britannica.com/science/lake, Lane, R. K., Physical feauture, accesed Sept. 2019.

http://www.complexturisticcostesti.md (accessed on 15.05.2019).

http://www.cpdr.org/main/publications, Danube River Basin Management Plan, accesed in Sept. 2019.

https://www.eea.europa.eu/data-and-maps/indicators/use-of-freshwater-resources-2/ assessment-3, Use of freshwater resources (accesed Sept. 2019.

http://fishhuntplaces.com (accessed on 15.05.2019).

https://qgis.org/en/site, Quantum GIS, accesed Sept. 2019.

http://www.otdyh.md (accessed on 15.05.2019

http://www.rowater.ro/daprut/default.aspx Administrația Națională „Apele Române”. Planul de management al spațiului hidrografic Prut Bârlad. Ciclul II. (2016). Available online.

http://rybalka.md (accessed on 15.05.2019).

http://www.statistica. md (accessed on 13.06.2019).

http://www.struguras.md (accessed on 18.05.2019).

http://www.enpi-info.eu_Environmental protection of international river basins (EPIRB), accesed Sept. 2019

http://www.geoportal.md, Fondul național de date geospațiale al Republicii Moldova, accesed Sept. 2019. 
